\title{
LOCKED ANTLERS OF MULE DEER AND WHITE-TAILED DEER
}

\section{by Kenneth Scheelhaase and Ross MacLennan,}

Saskatchewan Department of Natural Resources, Saskatoon

In late January, 1971 while working in the sandhill area two miles south and two and a half miles east of Harris, Saskatchewan, the senior author* found two buck deer lying dead on a knoll in low shrubs. The deer had their antlers locked together, apparently as a result of a fight during the previous mating season. Upon closer inspection it was discovered that one was a mule deer (Odocoileus hemionus) and the other a whitetail (O. virginianus).

The whitetail had four tines on the right antler and three on the left antler in typical pattern, while the mule deer had less regular antlers. Both sides of the antlers had two irregular points in addition to the normal tines. The right antler of the whitetail was locked into the left antler of the mule deer. Some of the * Before the submission of this article Kenneth Scheelhaase was killed in an automobile accident. irregular points on the mule deer antler were involved in this locking. The left antler tip of the whitetail was wedged against the skull of the mule deer on the left side of the ridge formed by the sagittal suture of the frontal bones. This ridge, and the springiness of the antlers, held the two very firmly together. The whitetail tine had penetrated the skin and made a small indentation in the mule deer skull, but no fracture was evident.

Very little is known about the occurrence of fighting between mule and white-tailed deer. The authors are aware of only one other documented case of locked mule deer and whitetail antlers. This involved antlers found northwest of Fort Walsh, Saskatchewan, by Mr. L. Dumont, in 1955 , and reported in the Records of North American Big Game (Webb, Fitz and Baker, 1958) and in a report

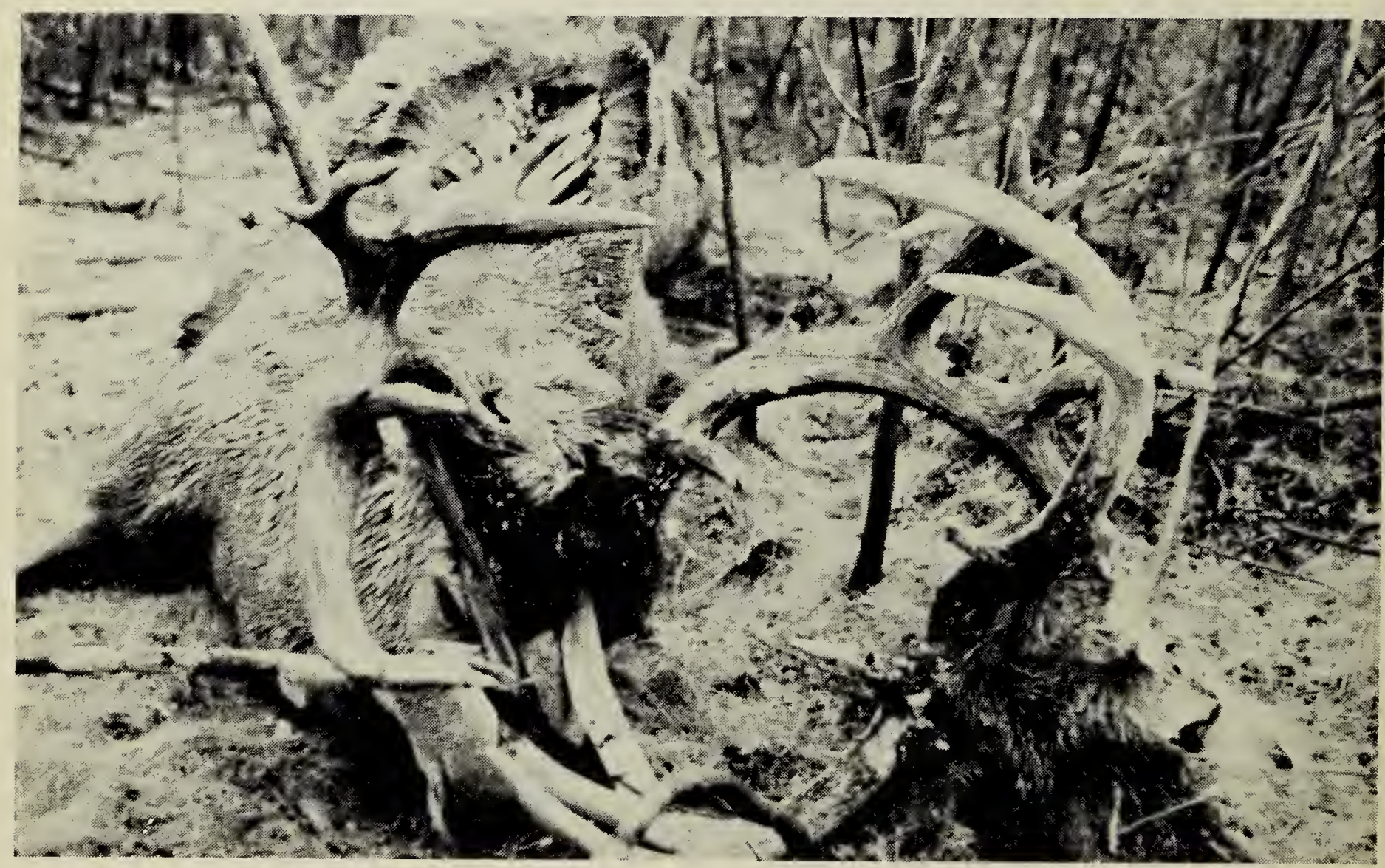

Locked antlers of Mule Deer and White-tailed Deer,

Photo by Ross MacLennan near Harris, May, 1971. 
on locked antlers by Notz (1965).

One may only speculate on the frequency of occurrence of aggressive interactions between the two species. While their distribution shows considerable overlap in west-central North America (Hall and Kelson, 1959), habitat variability usually provides for effective ecological separation in the overlap zone. Ecological separation, however, appears to be less developed in the relatively flat northern Great Plains and foothills, and thus the species may come into direct contact frequently in southwestern Saskatchewan and adjacent Alberta and Montana.

Likewise, we can only speculate on the behavioural significance of such interactions. Even in a species such as the whitetail in which many thousands of conspecific fights between males occur every year, locked antlers are a fairly rare occurrence. But the two instances of interspecific locked antlers in Saskatchewan indicate that head-to-head encounters between males of the two species may occur in areas where both are fairly abundant. Such interactions between male mule and white-tailed deer could, of course, merely represent the release of high levels of aggression toward the nearest available moving object. (For example, various male ungulates during the rutting period have been known to charge people, automobiles or even freight trains.) However, the usual function of ritualized frontal encounters in conspecific male ungulates is to establish dominance, which results in reproductive advantage. If this drive is the explanation for mule deer-whitetail combats, then it suggests that Pleistocene differentiation of the two species from a common stock did not proceed as far as complete behavioural isolation.

These apparently reproductively related interactions do not necessarily indicate actual mating of the species, much less the production of viable hybrids in the wild. However, the two species are known to interbreed in captivity (Taylor, 1956).

\section{Acknowledgments}

I would like to thank Don Blood, DNR, for assistace in the writing and editing of the manuscript and Hugo Maliepaard, DNR, for translation of the Notz paper.

\section{LITERATURE CITED}

Hall, R. E., and K. R. Kelson. 1959. The mammals of North America. The Ronald Press Co. New York. Vol. II. 536 pp.

Nutz, F. W. 1965. Uber Verkampfen bei altund neuweltlichem. Schalenwild. Wild und Hund, $68: 71-73$.

Taylor, W. P. 1956. The deer of North America. The Stackpole Co. Harrisburg, Pa. and the Wildl. Mgmt. Inst. Washington, D.C.

Webb, S. B., G. Fitz, and M. Baker. 1958. Records of North American big game. Henry Holt and Co. Inc. New York. 264 pp.

\title{
POPULATION SIZE AND PRODUCTIVITY OF THE BLACK-TAILED PRAIRIE DOG IN SASKATCHEWAN
}

\author{
by Larry Kerwin, 905 McKinnon Drive, Calgary, Alberta
}

Despite the concern of conservationists little is known about the status of the black-tailed prairie dog (Cynomys ludovicianus ludovicianus) in Canada. Paynter (1962) estimated that there were 45,000 animals in eight colonies inhabiting some 2,400 acres. An investigation during 1970 (Kerwin and Scheelhaase, 1971) revealed 16 colonies with an estimated 10,823 animals occupving about 1,244 acres. Some additional information is now available on the status of this species in southwestern Saskatchewan.

\section{METHODS}

Colonies were located during the summers of 1970 and 1971 and their location plotted on a 1:50,000 topographical map. The area of each colony was determined by planimeter. Several representative colonies were counted twice a week in both May and July to determine the breeding 